\title{
Use of Hydrous Manganese Oxides Nanopowders as a Potential Sorbent for Selective Removal of Nickel lons from Industrial Waste Water, Kinetics and Isotherm Studies
}

\author{
R. Ghaniem ${ }^{1}$, Y. A. El-Taweil ${ }^{1}$, M. E. Ossman ${ }^{2,3, *}$ \\ ${ }^{1}$ Chemical Engineering Department, Alexandria University, Alexandria, Egypt \\ ${ }^{2}$ Petrochemical Engineering Department, Pharos University, PUA, Alexandria, Egypt \\ ${ }^{3}$ Informatic Research Institute (IRI), City for Scientific Research and Technology Applications (CSRTA), Alexandria, Egypt
}

Email address:

Mhr1410@hotmail.com (M. E. Ossman)

${ }^{*}$ Corresponding author

\section{To cite this article:}

R. Ghaniem, Y. A. El-Taweil, M. E. Ossman. Use of Hydrous Manganese Oxides Nanopowders as a Potential Sorbent for Selective Removal of Nickel Ions from Industrial Waste Water, Kinetics and Isotherm Studies. American Journal of Chemical Engineering.

Vol. 4, No. 6, 2016, pp. 170-178. doi: 10.11648/j.ajche.20160406.15

Received: November 19, 2016; Accepted: December 1, 2016; Published: January 12, 2017

\begin{abstract}
Hydrous Manganese Oxides Nanopowders as nano adsorbent (MONs) was synthesized and characterized by Xray diffraction (XRD), scanning electron microscopy (SEM), and transform infrared spectroscopy (FT-IR). The adsorption of $\mathrm{Ni}$ (II) ions from aqueous solution on the MONs was investigated with variations in contact time, $\mathrm{pH}$, initial $\mathrm{Ni}$ (II) concentration and adsorbent dosage. The results showed that the adsorption of Ni (II) onto MONs increased within 25 min and reached equilibrium gradually and removal percentage were $83 \%, 57 \%, 42 \%$ and $35 \%$ for $25 \mathrm{ppm}, 50 \mathrm{ppm}, 75 \mathrm{ppm}$ and 100 ppm Ni (II), respectively, by using $1 \mathrm{~g} / 1$ MONs for $90 \mathrm{~min}$ at $\mathrm{pH}$ 6. The adsorption behavior of Ni (II) onto MONs was best described by the pseudo-second-order model and Freundlish isotherm. The results also indicated that the type of adsorption involved in this study is physiosorption (physical sorption) which usually takes place at low temperature. The results also revealed that MONs was a promising adsorbent for removal of $\mathrm{Ni}$ ions from industrial wastewater.
\end{abstract}

Keywords: Manganese Oxides, Nickel, Adsorption, Metal Oxides, Nano Adsorbent

\section{Introduction}

Water contamination with toxic heavy metals from the industrial wastewater activities have become a serious environmental and public health problem. With the rapid increase of global industrial activities, heavy metal pollution on water resources is considered a hazardous effect on human beings [1-3].

Heavy metals found their ways to the environment through wastewater streams of the modern industrial activities such as batteries, pesticides, fertilizer and paper industries, metal plating, and mining operations [4-5].

Contamination of waste water with heavy metals has got great attention since they are known to be toxic and nonbiodegradable [6].

Many treatment methods have been reported in the literatures which can be used to remove heavy metals from aqueous solutions. Among these methods are; the chemical precipitation, ion exchange, coagulation and electrochemical removal, but these methods led to high-energy requirements, and production of toxic sludge [7].

Other methods such as solvent extraction, biological, photo catalysis and adsorption are utilized to remove metal ions from aqueous solutions. Among of all these methods, adsorption was found to be the most effective method [8].

The adsorption process is affected by the characterizations of the adsorbent materials such as the surface morphology, adsorbent surface area, the pore volume, particle size distribution and functional groups attached to the adsorbent surface [9]. Huge numbers of adsorbents have been reported in several recent studies including activated carbon [10-15], synthetic polymers [16-19] and silica-based adsorbents [20]. These types of adsorbents suffer from intra-particle diffusion 
which decreases the adsorption rate due to the size of adsorbents. To overcome this limitation, preparation of nanoadsorbent has taken place. These nanoadsorbents have small diffusion resistance that increased the importance of using nanoparticles as adsorbent [21].

Many recent researches classified the nanosized metal oxides (nano metal oxides) as the promising adsorbents for heavy metals removal from aqueous systems [22-23]. But nanosized metal oxides suffer from their poor stability, because as the size of metal oxides reduces to nanometer levels, the surface energy increased. Also the nano metal oxides are tending to agglomeration because of Van der Waals forces; this will led to decrease the high capacity and selectivity of nano metal oxides [24].

Many recent studies for the adsorption of heavy metals from wastewater have been taken place. The most widely studied nano metal oxides include iron oxides, manganese oxides, aluminum oxides, $\mathrm{CuO}, \mathrm{NiO}, \mathrm{ZnO}$ and $\mathrm{TiO}_{2}$ [25-31].

In the present work, the synthesis of Nano manganese oxides (MONs) was studied. The prepared MONs was characterized with scanning electron microscope, a surface area analyzer, and X-ray diffraction. The prepared MONs was used for the removal of Nickel from simulated wastewater. The effects of different parameters such as contact time, adsorbent dosage, and solution $\mathrm{pH}$ have been studied. Further, the adsorption of nickel from aqueous solution was studied kinetically to explore and understand the adsorption mechanism.

\section{Material and Method}

All chemicals used were of analytical grade. Hydrated manganese chloride $\left(\mathrm{MnCl}_{2} .4 \mathrm{H}_{2} \mathrm{O}\right)$, Ethanol amine (EA).

\subsection{Preparation of the Nano Adsorbent}

$0.598 \mathrm{~g}$ of $\mathrm{MnCl}_{2} .4 \mathrm{H}_{2} \mathrm{O}$ and $30 \mathrm{ml}$ of EA were loaded into a beaker and stirred with magnetic stirrer for 25 minutes untill $\mathrm{MnCl}_{2} .4 \mathrm{H}_{2} \mathrm{O}$ was completely dissolved and forming a clear brown solution. Then $30 \mathrm{ml}$ of distilled water was added to the resulting solution and the solution was stirred at room temperature for 5 hours. The clear brown mixture turned to a dark brown suspension. The resulting suspension was then centrifuged at $7000 \mathrm{rpm}$ for $7 \mathrm{~min}$ to separate the dark brown precipitate which is washed thoroughly with Ethanol. The prepared dark brown precipitate was dispersed into solvents various organic solvents such as hexane, octane and toluene. The mixture was allowed to stand in air at room temperature then in an oven at $40-100{ }^{\circ} \mathrm{C}$ for 5 hours.

\subsection{Batch Experiments}

A stock solution of Nickel (1000 ppm) was prepared by dissolving $4.953 \mathrm{~g}$ of nickel nitrate, $\mathrm{Ni}\left(\mathrm{NO}_{3}\right)_{2} \cdot 6 \mathrm{H}_{2} \mathrm{O}$, (analytical reagent grade) in de-ionized distilled water and then add $10 \mathrm{~mL}$ of conc. Sulphuric acid and dilute to 1 liter with de-ionized distilled water.

Equilibrium isotherms for $\mathrm{Ni}$ (II) were obtained by performing batch adsorption studies. Solutions of $50 \mathrm{mg} / \mathrm{L}$ concentration were adjusted to optimum $\mathrm{pH}$ values and adsorbents amounts ranging between 0.05 and $0.4 \mathrm{~g}$ were added to solutions.

The adsorbed heavy metal amount $\left(q_{\mathrm{e}}\right)$ per unit absorbent mass was calculated as follows:

$$
q_{e}=\frac{\left(C_{0}-C_{e}\right) * V}{W}
$$

Where $C_{\mathrm{o}}$ is the initial heavy metal concentration, $C_{\mathrm{e}}$ is the concentration of heavy metal at equilibrium $(\mathrm{mg} / \mathrm{L}), W$ is the adsorbent mass (mg) and $V$ is the solution volume (L).

\subsection{Effect of $\mathrm{pH}$}

In order to optimize the $\mathrm{pH}$ for maximum removal efficiency, experiments at $25^{\circ} \mathrm{C}$ were carried out by taking into contact $100 \mathrm{~mL}$ of $100 \mathrm{ppm} \mathrm{Ni}$ (II) solution with $1 \mathrm{~g} / \mathrm{l}$ of $\mathrm{Mn}$ oxides nano powder and contact time $(30 \mathrm{~min})$ was kept constant by stirring and adjusting continuously the solution $\mathrm{pH}$ with $\mathrm{HCl}$ and $\mathrm{NaOH}$ solutions at different $\mathrm{pH}(2,4,6$ and 8).

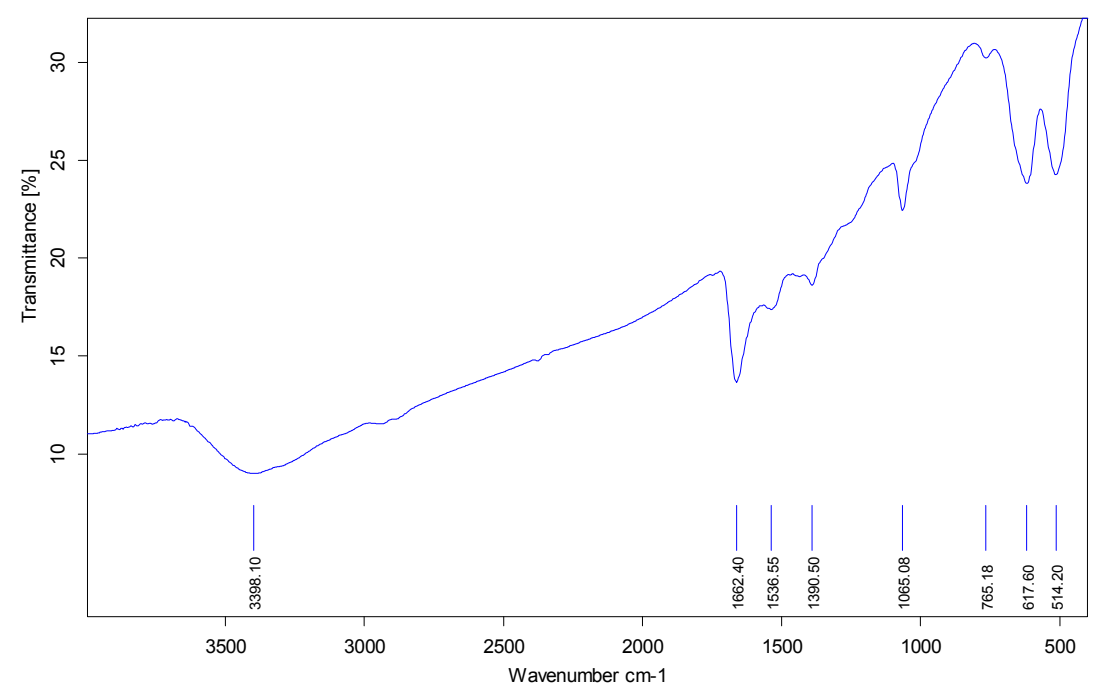

Figure 1. FTIR for Mn Oxides nano powder. 


\section{Results and Discussions}

\subsection{Characterization of Mn Oxides nano Powder Prepared}

\subsubsection{Fourier Transform Infra- Red (FTIR)}

FT-IR spectra of the prepared MnOxides sample are presented in Figure 1. The bands at 3398, 1662, 1536 and $1390 \mathrm{~cm}^{-1}$ are correspond to the $\mathrm{O}-\mathrm{H}$ vibrating mode of absorbed water. The band located at about $617 \mathrm{~cm}^{-1}$ is attributed to the metal-oxygen (Mn-O) bending vibration in $\delta-\mathrm{MnO}_{2}$. The bands located at $514 \mathrm{~cm}^{-1}$ belongs to the metaloxygen (Mn-O) bending vibration of $\left[\mathrm{MnO}_{6}\right]$ octahedral in $\alpha$ $\mathrm{MnO}_{2}$ [32], while the bands located at $765 \mathrm{~cm}^{-1}$ correspond to the metal-oxygen $(\mathrm{Mn}-\mathrm{O})$ bending vibration of $\beta-\mathrm{MnO}_{2}$ [33].

\subsubsection{SEM}

Morphological analysis of Mn Oxides nano powder were performed by scanning electron microscopy (SEM) in order to show the major features and morphology of the metal oxide powders. The morphological appearance is shown in Figure 2 and Table (1), it can be seen that the product particles are uniformly distributed and mainly composed of spherical particles with $20 \mathrm{~nm}$ of average grain size.

Table 1. Surface area of MONs.

\begin{tabular}{ll}
\hline BET surface area & $91.9749 \mathrm{~m}^{2} / \mathrm{g}$ \\
\hline Micropore volume & $0.002312 \mathrm{~cm}^{3} / \mathrm{g}$ \\
\hline
\end{tabular}
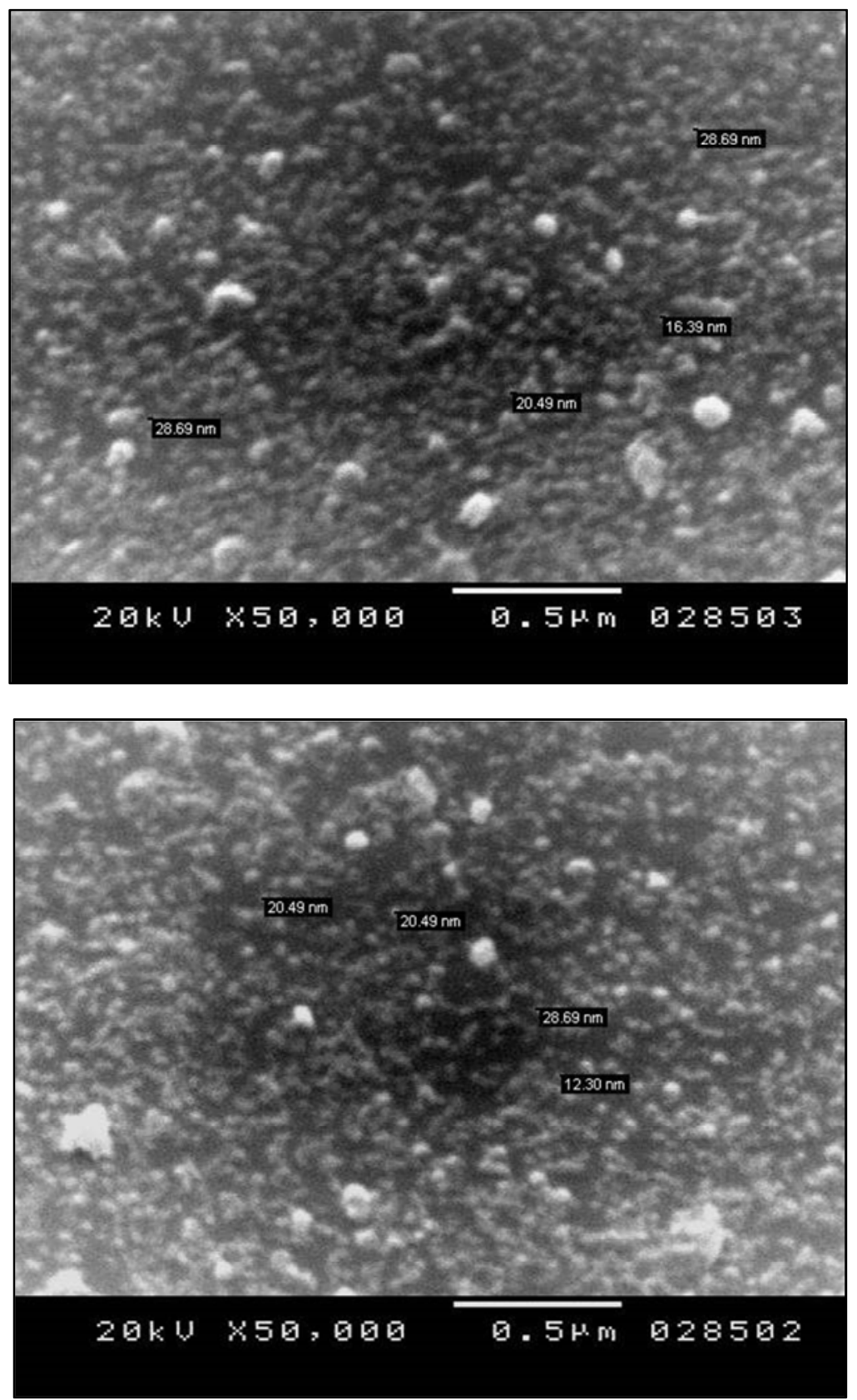

Figure 2. SEM for Manganese Oxide. 


\subsubsection{X-Ray Diffraction (XRD) Analysis}

Figure 3 represents the $\mathrm{X}$-ray diffraction pattern for the prepared Mn oxides particles. Here the nanoMn oxides particles were identified as a mixture of different phases such as $\mathrm{MnO}, \mathrm{MnO}_{2}$ and $\mathrm{Mn}_{3} \mathrm{O}_{4}$.

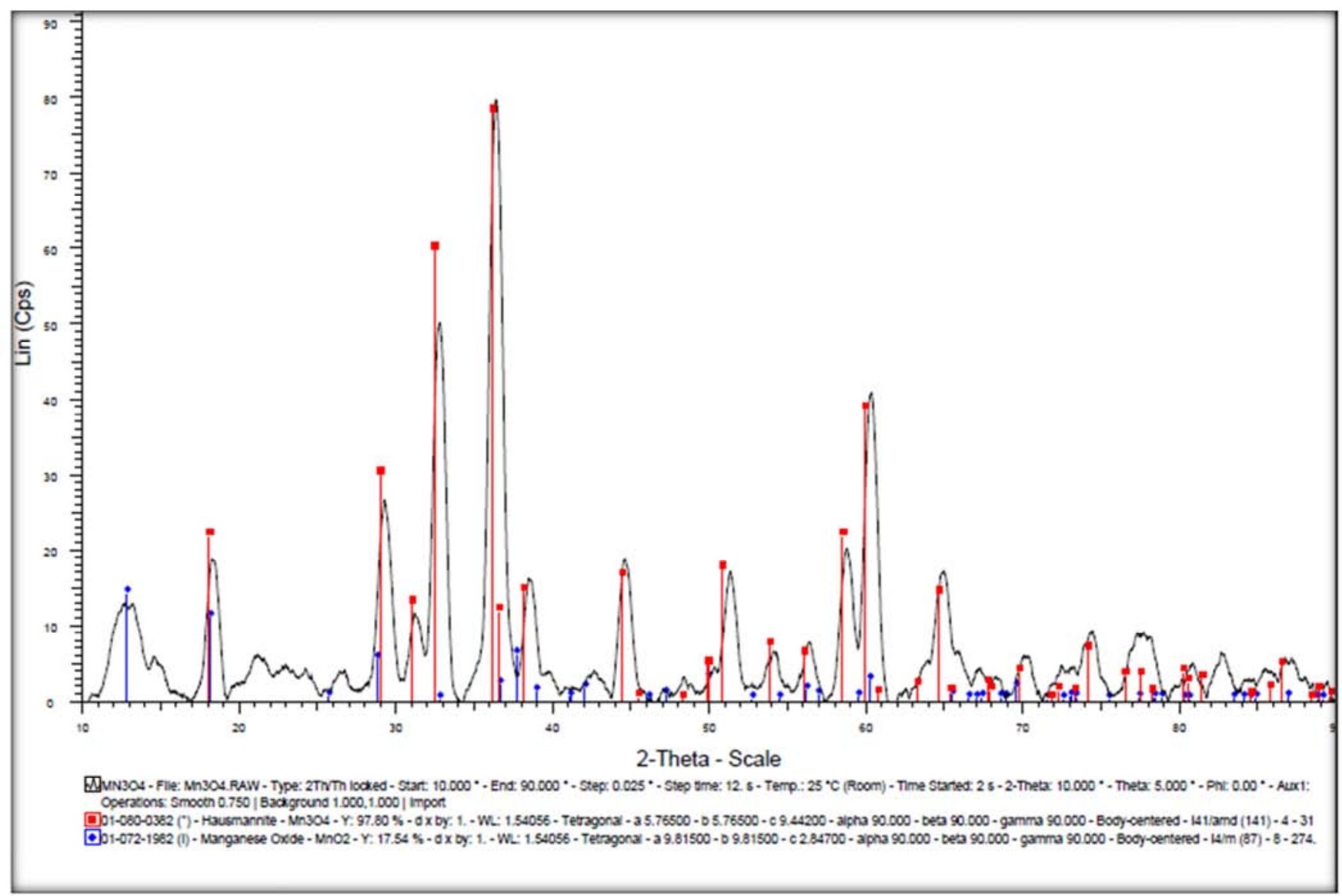

Figure 3. XRD analysis of Mn Oxides nano powder.

\subsection{Effect of Contact Time}

Effect of contact time on adsorption of $\mathrm{Ni}$ (II) (100 ppm) using batch reactor is presented in Figure 4 . The \% removal of $\mathrm{Ni}$ (II) were found to be $83 \%, 57 \%, 42 \%$ and $35 \%$ for $25 \mathrm{ppm}, 50 \mathrm{ppm}, 75 \mathrm{ppm}$ and $100 \mathrm{ppm} \mathrm{Ni}$ (II) respectively by using $1 \mathrm{~g} / \mathrm{l}$ Mn oxides nano-powder for $90 \mathrm{~min}$.

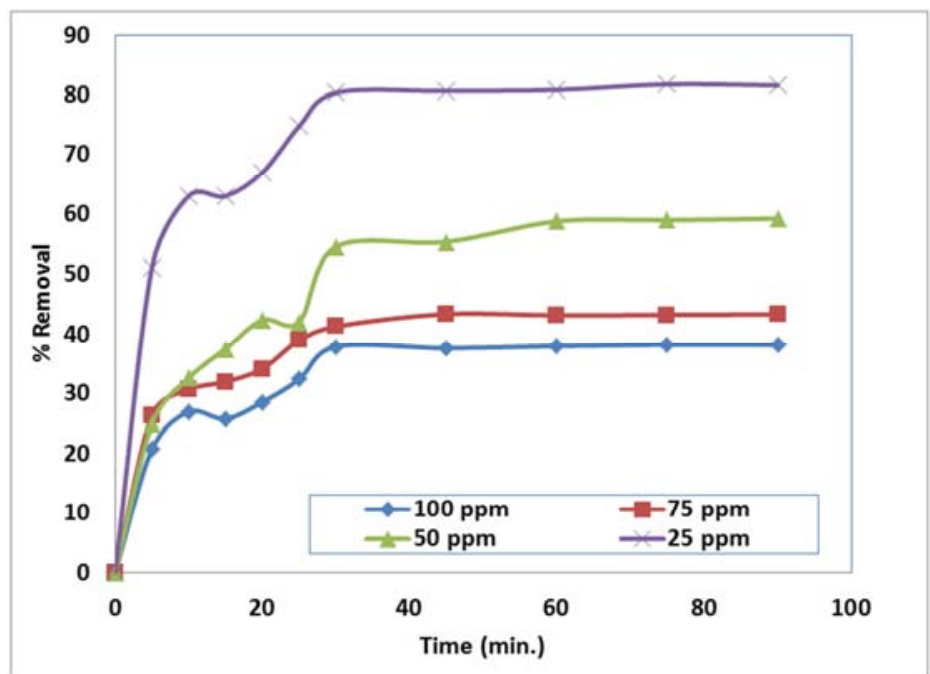

Figure 4. Effect of contact time on the adsorption capacity of (Mn Oxides nano powder) for Ni ions at different concentration and pH is 6, adsorbent dosage is $1 \mathrm{~g} / \mathrm{l}$ and Temperature is $25^{\circ} \mathrm{C}$. 


\subsection{Effect of $\mathrm{pH}$}

The acidity of solution $(\mathrm{pH})$ is one of the most important parameters controlling uptake of heavy metals from aqueous solutions. Figure 5 describes the effects of $\mathrm{pH}$ on adsorption capacity of $\mathrm{Ni}$ (II). The adsorption of $\mathrm{Ni}$ (II) was found to be incresed as $\mathrm{pH}$ increased till reached 8 . This results show good agreements with [34].

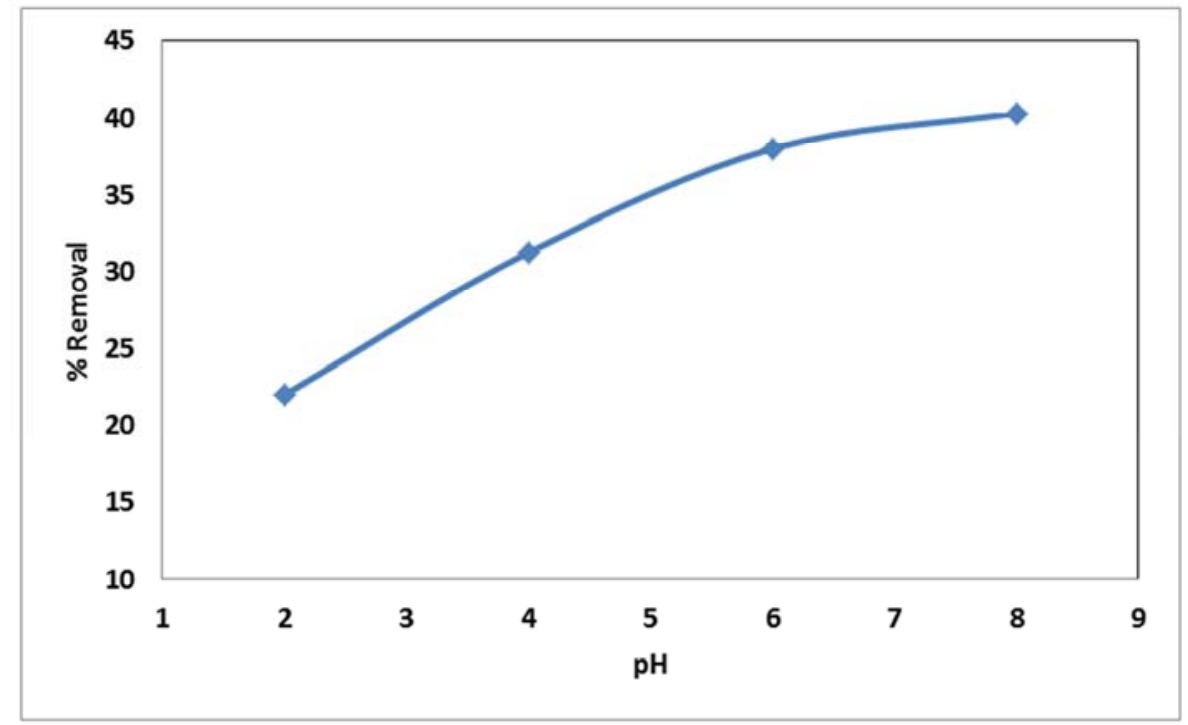

Figure 5. Effect of $\mathrm{pH}$ on the removal of $\mathrm{Ni}$ (II) at $100 \mathrm{ppm}$ initial concentration, $2 \mathrm{~g} / \mathrm{l}$ adsorbent dosage and at $25 \mathrm{C}$ for $30 \mathrm{~min}$.

\subsection{Effect of Adsorbent Dosage}

The results of the experiments with varying adsorbent dosage are presented in Figure 6. It was found that with an increase in the adsorbent dosage from 1 to $3 \mathrm{~g} / \mathrm{L}$, the $\%$ removal of $\mathrm{Ni}$ (II) increased from $37 \%$ to $63 \%$ in the batch reactor.

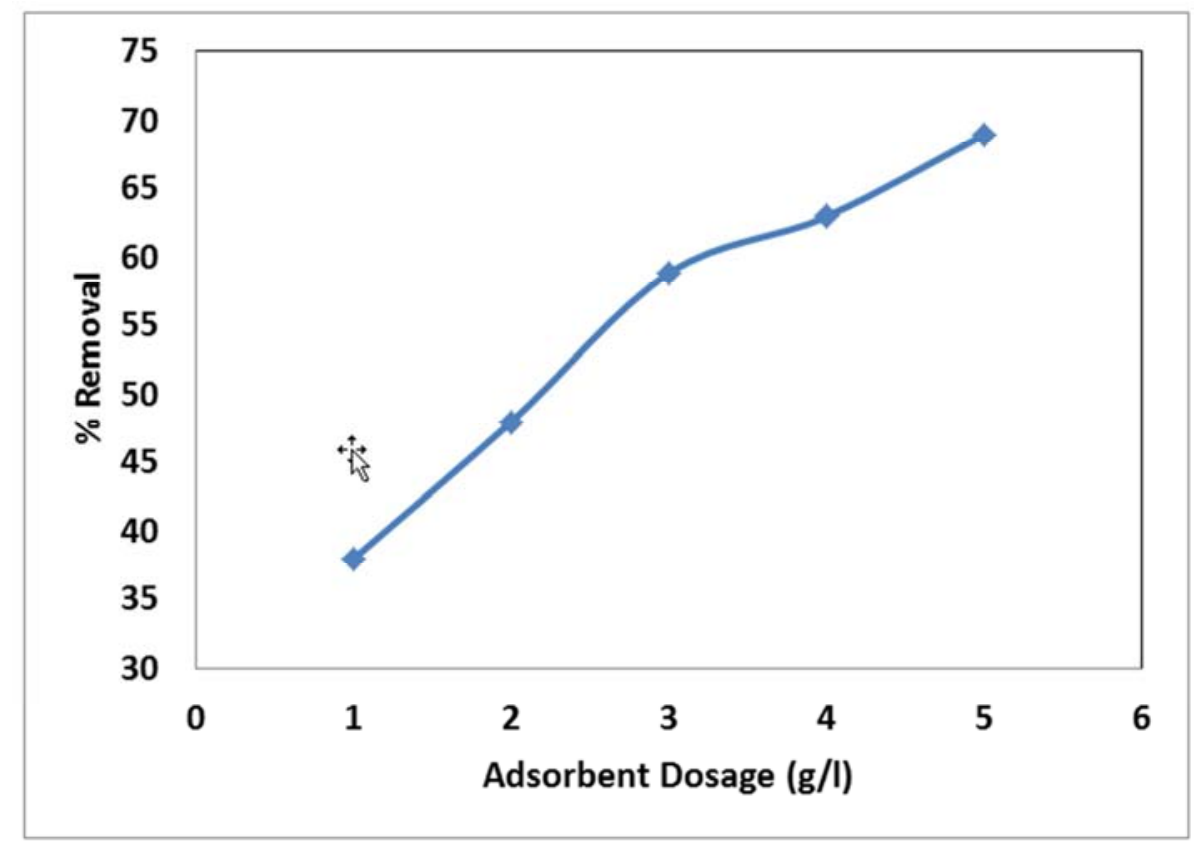

Figure 6. Effect of adsorbent dosage on the removal of $\mathrm{Ni}$ (II) at $100 \mathrm{ppm}$ initial concentration, $6 \mathrm{pH}$ and at $25 \mathrm{C}$ for $30 \mathrm{~min}$.

\subsection{Modeling of Adsorption Isotherm}

The most widely accepted surface adsorption models for single-solute systems are the Langmuir and Freundlich models.

\subsubsection{The Langmuir Isotherm}

The adsorption data was tested using Langmuir isotherm equation in the linearized form: 


$$
\frac{C_{e}}{q_{e}}=\frac{1}{q_{\max } b}+\frac{1}{q_{\max }} C_{e}
$$

Where $C_{\mathrm{e}}$ is the equilibrium concentration of the $\mathrm{Ni}$ (II) in solution $\left(\mathrm{mg} \mathrm{L}^{-1}\right), \mathrm{q}_{\mathrm{e}}$ is the adsorption capacity at equilibrium $\left(\mathrm{mg} \mathrm{g}^{-1}\right), b\left(\mathrm{~L} \mathrm{mg}^{-1}\right)$ Langmuir constants, related to the binding constant and $q_{\max }\left(\mathrm{mg} \mathrm{g}^{-1}\right)$ is the maximum adsorption capacity. A plot of specific sorption $\left(\mathrm{C}_{\mathrm{e}} / \mathrm{q}_{\mathrm{e}}\right)$ versus $\mathrm{C}_{\mathrm{e}}$ gives a straight line of slope $\left(1 / \mathrm{q}_{\max }\right)$ and intercepts $\left(1 / \mathrm{q}_{\max }\right.$ b) as given in Table 2 .

\subsubsection{The Freundlich Isotherm}

The Freundlich isotherm is commonly given by the following non-linear equation:

$$
q_{e=K_{F}} C_{e}^{1 / n}
$$

Where $K_{\mathrm{F}}$ is a Freundlich constant; related to the bonding energy. $K_{\mathrm{F}}$ can be defined as the adsorption or distribution coefficient and represents the quantity of $\mathrm{Ni}$ (II) adsorbed onto adsorbent for unit equilibrium concentration. $1 / n$ indicates the adsorption intensity of $\mathrm{Ni}$ (II) onto the sorbent with surface heterogeneity, becoming more heterogeneous as its value gets closer to zero. Eq. (3) can be linearized according to the logarithmic Eq. (4) and the Freundlich constants can be determined:

$$
\log q_{e}=\log K_{F}+\frac{1}{n} C_{e}
$$

The applicability of the Freundlich sorption isotherm was analyzed, using the same set of experimental data, by plotting $\log (q \mathrm{e})$ versus $\log (C \mathrm{e})$. The data obtained from the linear Freundlich isotherm plot for the adsorption of $\mathrm{Ni}$ (II) on $\mathrm{Mn}$ Oxides nano powder is presented in Table 2. The correlation coefficients reported in Table 2 showed strong positive evidence that the adsorption of $\mathrm{Ni}$ (II) onto Mn Oxides nano powder follows the Freundlich isotherm for 100ppm Ni (II) concentration.

\subsubsection{The Dubinin-Radushkevich (D-R) Isotherm}

The D-R model was also applied to estimate the characteristic porosity of the adsorbent, the apparent energy of adsorption and the characteristics of adsorption on micropores rather than on a layer-by-layer adsorption [35, 36]. The D-R model has commonly been applied in the following Eq. (5) and its linear form can be shown in Eq. (6)

$$
\begin{gathered}
\mathrm{q}_{\mathrm{e}}=\mathrm{Q}_{\mathrm{m}} \exp \left(-\mathrm{B} \varepsilon^{2}\right) \\
\ln \mathrm{q}_{\mathrm{e}}=\ln \mathrm{Q}_{\mathrm{m}}-\mathrm{B} \varepsilon^{2}
\end{gathered}
$$

Where $B$ is a constant related to the adsorption energy $\left(\mathrm{mol}^{2} \mathrm{~J}^{2}\right), Q_{\mathrm{m}}$ the theoretical saturation capacity $\left(\mathrm{mg} \mathrm{g}^{-1}\right), \varepsilon$ the Polanyi potential, calculated from Eq. (7).

$$
\varepsilon=\mathrm{RT} \ln (1+1 / \mathrm{Ce})
$$

The slope of the plot of $\ln q$ e versus $\varepsilon^{2}$ gives $B\left(\mathrm{~mol}^{2}\left(\mathrm{~kJ}^{2}\right)^{-1}\right)$ and the intercept yields the adsorption capacity, $Q_{\mathrm{m}}\left(\mathrm{mg} \mathrm{g}^{-1}\right)$. The mean free energy of adsorption, $E\left(\mathrm{~kJ} \mathrm{~mol}^{-1}\right)$, defined as the free energy change when one mole of ion is transferred from infinity to the surface of the solid from the aqueous phase in the solution, was calculated from the $B$ value using the following relations [36]:

$$
\mathrm{E}=1 / \sqrt{ }(-2 \mathrm{~B})
$$

It can be used to estimate the type of adsorption. If the value is in the range $8-16 \mathrm{~kJ} \mathrm{~mol}^{-1}$, then the adsorption type can be explained by ion exchange, and if $\mathrm{E}<8$, the adsorption type is physiosorption [37-38]. The value of $E$ calculated using Eq. (8) is $0.5 \mathrm{~kJ} \mathrm{~mol}^{-1}$ for Mn Oxides nano powder. It shows that the type of adsorption involves in this study is physiosorption (physical sorption) which usually takes place at low temperature [39-40].

Table 2. Langmuir and Freundlish models for the removal of Ni (II) onto $\mathrm{Mn}$ oxides nanopowder using batch reactor.

\begin{tabular}{ll}
\hline Isotherm model & \\
\hline Langmuir & \\
\hline $\mathrm{Q}^{0}\left(\mathrm{mg} \mathrm{g}^{-1}\right)$ & 39.06 \\
$\mathrm{~K}_{\mathrm{a}}\left(\mathrm{L} \mathrm{mg}^{-1}\right)$ & 0.25 \\
No. of parameter estimated & 2 \\
Data point available & 440.9316 \\
$\mathrm{R}^{2}$ & \\
Freundlich & 0.2332 \\
$1 / \mathrm{n}$ & 14.94 \\
$\mathrm{~K}_{\mathrm{F}}\left(\mathrm{mg} \mathrm{g}^{-1}\right)$ & 2 \\
$\mathrm{No}$ of parameter estimated & 4 \\
Data point available & 0.9612 \\
$\mathrm{R}^{2}$ & \\
$\mathrm{D}-\mathrm{R} \mathrm{isotherm}$ & 35.82 \\
$\mathrm{Q}_{\mathrm{m}}\left(\left(\mathrm{mg} \mathrm{g}^{-1}\right)\right.$ & 2 \\
$\mathrm{~B}\left(\mathrm{~mol}^{2} \mathrm{~kJ}^{-2}\right)$ & 0.5 \\
$\mathrm{E}\left(\mathrm{kJ} \mathrm{mol}^{-1}\right)$ & 0.8112 \\
$\mathrm{R} 2$ & \\
\hline
\end{tabular}

\subsection{Kinetics of Adsorption}

\subsubsection{Pseudo-First-Order Equation}

The adsorption kinetic data were described by the Lagergren pseudo-first-order model [41] which is the earliest known equation describing the adsorption rate based on the adsorption capacity. The linear form equation is generally expressed as follows:

$$
\ln \left(q_{e}-q_{t}\right)=\ln q_{e}-K t
$$

In order to obtain the rate constants, the values of $\ln \left(q_{\mathrm{e}}-q_{t}\right)$ were linearly correlated with $t$ by plot of $\ln (q \mathrm{e}-q t)$ versus $t$ to give a linear relationship from which $\mathrm{K}_{1}$ and predicted $q_{\mathrm{e}}$ can be determined from the slope and intercept of the plot, respectively.

\subsubsection{Pseudo-Second-Order Equation}

The adsorption kinetic may be described by the pseudosecond order model. The linear equation is generally given as follows:

$$
\frac{\mathrm{t}}{\mathrm{q}_{\mathrm{t}}}=\frac{1}{\mathrm{~K}_{2}} \frac{1}{\mathrm{q}_{\mathrm{e}}^{2}}+\frac{1}{\mathrm{q}_{\mathrm{e}}} \mathrm{t}
$$

If the second-order kinetics is applicable, then the plot of $t / q_{t}$ versus $t$ should show a linear relationship. Values of $\mathrm{K}_{2}$ 
and equilibrium adsorption capacity $q_{\mathrm{e}}$ were calculated from the intercept and slope of the plots of $t / q_{t}$ versus $t$. The linear plots of $t / q_{t}$ versus $t$ show good agreement between experimental and calculated $q_{\mathrm{e}}$ values (Table 3). The correlation coefficients for the pseudo second-order kinetic model are greater than 0.99 , which led to believe that the pseudo second order kinetic model provided good correlation for the adsorption of $\mathrm{Ni}$ (II) onto Mn Oxides nano powder.

The adsorbate transported from the bulk solution phase to the internal active sites occurs in several steps, where the rate of internal mass transfer is in most cases the rate-determining step in adsorption processes. Kinetic data were used further to check the possibility of intra-particle diffusion by using the Weber and Morris equation expressed by the following equation;

$$
q t=k_{d} t^{0.5}+c
$$

where $\mathrm{q}_{\mathrm{t}}\left(\mathrm{mg} \mathrm{g}^{-1}\right)$ is the amount of adsorbed Ni (II) at time $\mathrm{t}$ and $k_{\mathrm{d}}$ is the intra-particle diffusion rate constant $\left(\mathrm{mg} \mathrm{g}^{-1}\right.$ $\min ^{-0.5}$ ), and $c$ is a constant determined from the intercept. If the plot of $q_{\mathrm{t}}$ versus $t^{0.5}$ gives a straight line passing through the origin, then the adsorption process is only controlled by intra-particle diffusion, if multi-linearity in qt vs. $\mathrm{t}^{1 / 2}$ plot is considered (that is, two or three steps are involved to follow the whole process) Figure 7 shows that the external surface adsorption occurs in the first step; the second step is the gradual adsorption step, where intraparticle diffusion is controlled; and the third step is the final equilibrium step, where the solute moves slowly from larger pores to micropores causing a slow adsorption rate.

Table 3. Kinetic parameters for the adsorption of Ni (II) onto Mn oxides nano powder for 100ppm Ni concentration.

\begin{tabular}{|c|c|c|c|c|c|c|}
\hline \multirow{2}{*}{ Conc. (ppm) } & \multicolumn{3}{|c|}{ Pseudo first order kinetics } & \multicolumn{3}{|c|}{ Pseudo second order kinetics } \\
\hline & $K_{1}\left(\min ^{1}\right)$ & $q_{1}\left(\mathrm{mg} \mathrm{g} \mathrm{g}^{-1}\right)$ & $\mathbf{R}^{2}$ & $\mathrm{~K}_{2}\left(\mathrm{~g} \mathrm{mg}^{-1} \mathrm{~min}^{-1}\right)$ & $q_{2}\left(\mathrm{mg} \mathrm{g}^{-1}\right)$ & $\mathbf{R}^{2}$ \\
\hline 100 & 0.0643 & 36.56 & 0.8532 & 0.0036 & 45.66 & 0.9953 \\
\hline 75 & 0.0761 & 31.42 & 0.8479 & 0.0027 & 35.36 & 0.9939 \\
\hline 50 & 0.0592 & 27.62 & 0.9624 & 0.0057 & 35.59 & 0.9978 \\
\hline 25 & 0.0376 & 12.17 & 0.9139 & 0.012 & 22.78 & 0.9983 \\
\hline
\end{tabular}

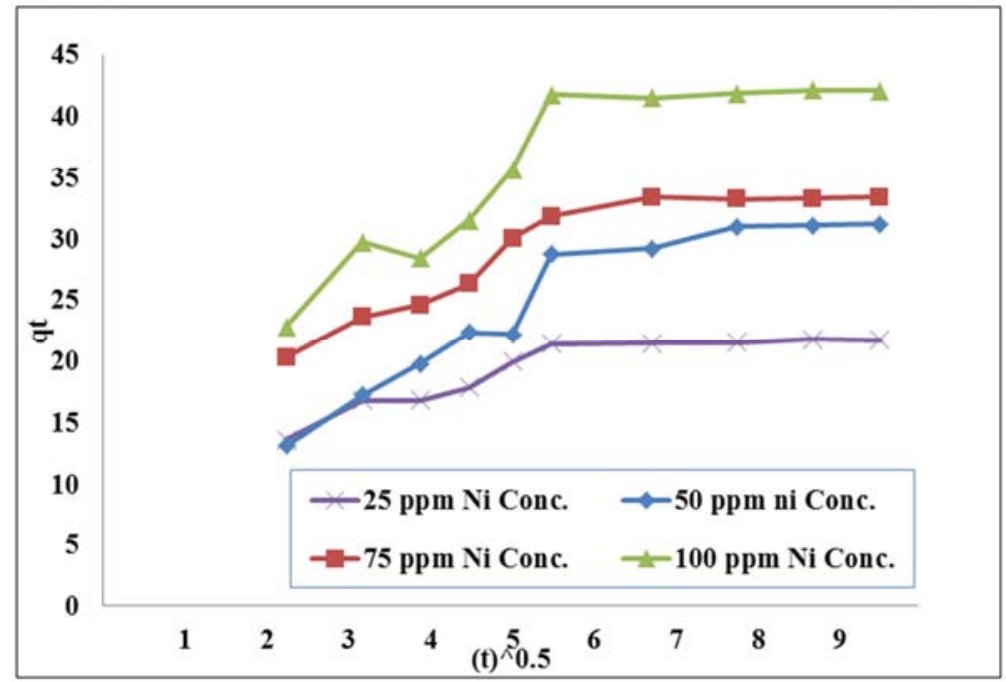

Figure 7. Intra-particle diffusion for adsorption of Ni at different concentrations by Mn oxides nano powder using batch reactor.

\section{Conclusions}

Mixture of Manganese Oxides Nanopowders as nano adsorbent (MONs) was synthesized and characterized by Xray diffraction (XRD), scanning electron microscopy (SEM), and transform infrared spectroscopy (FT-IR). It has been used for removal of $\mathrm{Ni}$ (II) ions from aqueous solution. The results showed that the maximum adsorption capacities of $\mathrm{Ni}$ (II) onto MONs were $35 \mathrm{mg} / \mathrm{g}$. The adsorption behavior of $\mathrm{Ni}$ (II) onto MONs was best described by the pseudo-secondorder model and Freundlish isotherm. The results also indicated that the type of adsorption involves in this study is physiosorption (physical sorption) and the external surface adsorption occurs in the first step; the second step is the gradual adsorption step, where intraparticle diffusion is controlled; and the third step is the final equilibrium step, where the solute moves slowly from larger pores to micropores causing a slow adsorption rate. The results also revealed that MONs is a promising adsorbent for removal of $\mathrm{Ni}$ (II) from industrial wastewater.

\section{References}

[1] M. Jamil, M. S. Zia, M. Qasim, Contamination of agroecosystem and human health hazards from wastewater used for irrigation, J. Chem. Soc. Pak. 32 (2010), 370-378.

[2] S. Khan, Q. Cao, Y. Zheng, Y. Huang, Y. Zhu, Health risks of heavy metals incontaminated soils and food crops irrigated with wastewater in Beijing, China, Environ. Pollut. 152 (2008), 686-692. 
[3] A. Singh, R. K. Sharma, M. Agrawal, F. M. Marshall, Health risk assessment of heavy metals via dietary intake of foodstuffs from the wastewater irrigated site of a dry tropical area of India, Food Chem. Toxicol. 48 (2010), 611-619.

[4] N. G. Kandile, H. M. Mohamed, M. I. Mohamed, New hetero cycle modified chitosan adsorbent for metal ions (II) removal from aqueous systems, Int. J. Biol. Macromol. 72 (2015), $110-116$.

[5] D. Pathania and P. Singh. Nanosized, Metal Oxide-Based Adsorbents for Heavy Metal Removal: A Review Advanced Materials for Agriculture, Food, and Environmental Safety, (2014), 243-264.

[6] F. Fu, Q. Wang, Removal of heavy metal ions from wastewaters: A review, J. Environ. Manage. 92 (2011), 407-418.

[7] H. Eccles, Treatment of metal-contaminated wastes: why select a biological process? Trends Biotechnol. 17 (1999), $462-465$.

[8] R. M. Ali, H. A. Hamad, M. M. Hussein, G. F. Malash, Potential of Using green adsorbent of heavy metal removal from aqueous solutions: Adsorption kinetics, isotherm, thermodynamic, mechanism and economic analysis, Ecological Engineering, 91 (2016), 317-332.

[9] A. Ewecharoena, P. Thiravetyan, E. Wendel, H. Berlagnolli, Nickel adsorption by sodium polyacrylate-grafted activated carbon, J. Hazard. Mater. 171 (2009), 335-339.

[10] M. Karnib, A. Kabbani, H. Holail, Z. Olama, Heavy metals removal using activated carbon: silica and silica activated carbon composite. Energy Procedia, 50 (2014), 113-120.

[11] M. E. Ossman, M. Abdel Fatah \&Nahla A. Taha, Fe (III) removal by activated carbon produced from Egyptian rice straw by chemical activation, Desalination and Water Treatment, 52 (16-18), (2014), 3159-3168.

[12] D. Lakherwal, V. K. Rattan, H. P. Singh. Studies on Adsorption of Nickel by Activated Carbon in a Liquid Fluidized Bed Reactor, Canad. Chem. Trans. 4 (2016), 121132.

[13] Z. Guo, J. Fan, J. Zhang, Y. Kang, H. Liu, L. Jiang, C. Zhang, Sorption heavy metal ions by activated carbons with welldeveloped micro porosity and amino groups derived from Phragmitesaustralis by ammonium phosphates activation. J. Taiw. Instit. Chem. Engi. 58 (2016), 290-296.

[14] S. Yao, J. Zhang, D. Shen, R. Xiao, S. Gu, M. Zhao, J. Liang, Removal of $\mathrm{Pb}$ (II) from water by the activated carbon modified by nitric acid under microwave heating, Journal of Colloid and Interface Science, 463 (2016), 118-127.

[15] S. Mashhadi, R. Sohrabi, H. Javadian, M. Ghasemi, I. Tyagi, S. Agarwal, V. K. Gupta, Rapid removal of $\mathrm{Hg}$ (II) from aqueous solution by rice straw activated carbon prepared by microwave-assisted $\mathrm{H}_{2} \mathrm{SO}_{4}$ activation: Kinetic, isotherm and thermodynamic studies, Journal of Molecular Liquids, 215 (2016), 144-153.

[16] H. Al-Zoubi, K. A. Ibrahim, Kh. A. Abu-Sbeih, Removal of heavy metals from wastewater by economical polymeric collectors using dissolved air flotation process, Journal of Water Process Engineering, 8 (2015), 19-27.

[17] S. Lapwanit, T. Trakulsujaritchok, P. N. Nongkhai, Chelating magnetic copolymer composite modified by click reaction for removal of heavy metal ions from aqueous solution, Chemical Engineering Journal, 289 (2016), 286-295.

[18] M. Cegłowski, G. Schroeder, Removal of heavy metal ions with the use of chelating polymers obtained by grafting pyridine-pyrazole ligands onto polymethylhydrosiloxane, Chemical Engineering Journal, 259 (2015), 885-893.

[19] A. Maleki, E. Pajootan, B. Hayati, Ethyl acrylate grafted chitosan for heavy metal removal from wastewater: Equilibrium, kinetic and thermodynamic studies, Journal of the Taiwan Institute of Chemical Engineers, 51 (2015), 127-134.

[20] P. Wang, M. Du, H. Zhu, S. Bao, T. Yang, M. Zou. Structure regulation of silica nanotubes and their adsorption behaviors for heavy metal ions: $\mathrm{pH}$ effect, kinetics, isotherms and mechanism, J. Hazard. Mater. 286 (2015), 533-544.

[21] T. M. S. Attia, X. L. Hu, D. Q. Yin, Synthesized magnetic nanoparticles coated zeolite (MNCZ) for the removal of arsenic (As) from aqueous solution, J. Exp. Nanosci. 1 (2012), $1-10$.

[22] H. K. Moghaddam and M. Pakizeh, Experimental study on mercury ions removal from aqueous solution by $\mathrm{MnO}_{2} / \mathrm{CNTs}$ nano composite adsorbent, J. Ind. Eng. Chem. 21 (2015), 221229.

[23] M. R. Awual, M. M. Hasan and H. Znad, Organic-inorganic based nanoconjugate adsorbent for selective palladium (II) detection, separation and recovery, Chem. Eng. J. 259 (2015), 611-619.

[24] T. Pradeep, Anshup, Noble metal nanoparticles for water purification: a critical review, Thin Solid Films, 517 (2009) 6441-6478.

[25] Z. Cheng, A. L. KuanTan, Y. Tao, D. Shan, K. E. Ting, and X J. Yin, Synthesis and characterization of iron Oxide nanoparticles and applications in the removal of heavy Metals from industrial wastewater, International Journal of Photoenergy, 2012 (2012), 1-5.

[26] A. M. Mahmoud, F. A. Ibrahim, S. A. Shaban, N. A. Youssef. Adsorption of heavy metal ion from aqueous solution by nickel oxide nano catalyst prepared by different methods, Egyptian Journal of Petroleum, 24 (1), (2015), 27-35.

[27] I. Ghiloufi, Effect of indium concentration in zinc oxide nanoparticles on heavy metals adsorption from aqueous solution, $5^{\text {th }}$ WSEAS International conference on Nanotechnology, (2013), 329-335, Cambridge, UK.

[28] J. Du and C. Jing, Preparation of Fe3O4 @Ag SERS substrate and its application in environmental $\mathrm{Cr}$ (VI) analysis, Journal of Colloid and Interface Science, 358 (2011), 54-61.

[29] S. Singh, K. C. Barick and D. Bahadur, Surface engineered magnetic nanoparticles for removal of toxic metal ions and bacterial pathogens, Journal of Hazardous Materials, 192 (2011), 1539-1547.

[30] J. F. Liu, Z. S. Zhao and G. B. Jiang, Coating Fe3O4 Magnetic Nanoparticles with Humic Acid for High Efficient Removal of Heavy Metals in Water, Environmental Science \& Technology, 42 (2008), 6949-6954.

[31] C. M. Chou and H. L. Lien, Dendrimer-conjugated magnetic nanoparticles for removal of zinc (II) from aqueous solutions, Journal of Nanoparticle Research, 13 (2011), 2099-2107. 
[32] H E. Wang, D. Qian, Synthesis and electrochemical properties of $\alpha-\mathrm{MnO}_{2}$ microspheres, Mater. Chem. Phys. $109(2 / 3)$ (2008), 399-403.

[33] L. X. Zhang, C. S. Liu, L. Zhuang, Manganese dioxide as an alternative cathodic catalyst to platinum in microbial fuel cells. Biosens. Bioelectron, 24 (9), (2009), 2825-2829.

[34] C. A. C. Rosas, M. Franzreb, F. Valenzuela, W. H. Holl, Magnetic manganese dioxide as an amphoteric adsorbent for removal of harmful inorganic contaminants from water, Reactive and functional polymers, 70 (2010), 516-520.

[35] M. M. Dubinin, Modern state of the theory of volume filling of micropore adsorbents during adsorption of gases and steams on carbon adsorbents, Zhurnal FizicheskoiKhimii. 39 (1965), 1305-1317.

[36] L. V. Radushkevich, Potential theory of sorption and structure of carbons, Zhurnal FizicheskoiKhimii. 23 (1949), 1410-1420.

[37] S. Kundu, A. K. Gupta, Investigation on the adsorption efficiency of iron oxide coated cement (IOCC) towards As (V)-kinetics, equilibrium and thermodynamic studies, Colloid Surf. A: Physicochem. Eng. Aspects 273 (1949), 121-128.

[38] P. B. Bhakat, A. K. Gupta, S. Ayoob, S. Kundu, Investigations on arsenic (V) removal by Modified Calcined Bauxite, Journal of Colloids and Interfaces A: Physicochemical and Engineering Aspects, 281 (2006), 237245.

[39] P. Bhunia, A. Pal and M. Bandyopadhay, Assessing arsenic leachability from pulverized cement concrete produced from arsenic-laden solid CalSiCo-sludge. J. Hazard. Mater. 141 (2007), 826.

[40] V. J. Inglezakis, S. G. Poulopoulo, Adsorption, Ion exchange and Catalysis: Design, Operation and Environmental Application, Elsevier, Amsterdam, The Netherland, 2006.

[41] S. Lagergren, Zur theorie der sogenannten adsorption geloster stoffe, Kungliga Svenska Vetenskapsakademiens. Handlingar, 24 (4) (1898). 